\title{
Flood mitigation efforts through community empowerment in Medan City, North Sumatera
}

\author{
Ilham Mirzaya Putra *, Efi Brata Madya \\ Universitas Islam Negeri Sumatera Utara. Jl. Williem Iskandar Pasar V, Medan, 20371 Indonesia \\ * Corresponding author. Email: ilhammirzaya@uinsu.ac.id
}

Received: 22 June 2020; Revised: 22 October 2020; Accepted: 22 October 2020

\begin{abstract}
This research aims to provide solutions in flood disaster countermeasure in Medan based on community empowerment. The research method used was descriptive qualitative research with a literature study approach and forum group discussion. Empowerment in this study consisted of aspects of knowledge and appreciation of the environment and community adherence to environmental-related regulations. The results of this study are: (1) Community knowledge about the environment can be improved by socialization activities, socialization activities are the beginning to raise environmental awareness; (2) Knowledge is not enough without appreciation, then community assistance activities are carried out by activating tourism, biopori, and utilization waste so that it has economic value, and (3) Enforcement of the law on the environment must be strictly enforced in order to create a deterrent effect for the community in violation.
\end{abstract}

Keywords: community empowerment, environment, flood.

How to Cite: Putra, I., \& Madya, E. (2020). Flood mitigation efforts through community empowerment in Medan City, North Sumatera. JPPM (Jurnal Pendidikan dan Pemberdayaan Masyarakat), 7(2), 172-179. doi:https://doi.org/10.21831/jppm.v7i2.32634

\section{PENDAHULUAN}

Medan is the capital of the province of North Sumatra with a population of 2,210,624 people (Statistics Indonesia: 2018) at night and nearly 2,6 million during the day (there are \pm 400 people as commuters) with an area of 26.510 hectares $\left(265.10 \mathrm{~km}^{2}\right)$, or $3.6 \%$ of the total area of the province of North Sumatra. The combination of rice between the population density, commuters (commuters) and job seekers makes the role of Medan City as a regional service centre must increase the carrying capacity of the region. The increase of Medan city population each year means that the population density ratio also increases. In contrast, the area of the city of Medan does not change increasingly regional challenges are increasingly significant. Therefore, the tendency of increasingly narrow land areas has the opportunity to trigger an imbalance between the carrying capacity and the existing environmental capacity.

The city of Medan is crossed by the Deli, Babura, Belawan, Percut and its tributaries which have the potential as rainwater drainage to deal with floods and sewage. But the opposite happened; even the flood disaster occurred mostly along the river flow area. Disaster flooding in Medan city that almost average 10-12 times/year greatly affected by the condition Watershed Deli river. Sungai Deli is the primary channel supporting the drainage of the city of Medan with a wide coverage of service areas, about $51 \%$ of the area of Medan. However, flooding in the city of Medan itself is one of them due to poor drainage conditions. It also caused limitations of Deli river capacity to accommodate the flow of water in because of the right number of buildings, whether residential buildings, offices, and industry along the riverbanks.

The study entitled "The Study of Flood Potential in Belawan River Area with Geographic Information System" (Zevri, 2019) found that there are $\pm 40.07 \mathrm{~km}^{2}-112.10 \mathrm{~km}^{2}$ of flood inundation covering nine urban villages occurring in residential, industrial, and transportation 


\section{JPPM (Jurnal Pendidikan dan Pemberdayaan Masyarakat), 7 (2), 2020 - 173}

Ilham Mirzaya Putra, Efi Brata Madya

areas. The flooding occurred due to the high population, increased runoff, destruction of water catchment areas, lack of drainage maintenance, and public awareness. Then the next study, entitled "The Details e d Design Study on Medan Flood Control Project" (Infrastructure, 2001), suggests that creating a spillway (floodway) expected would divert flood at the Deli River to River Percut before entering the city of Medan. However, this hope has not been realized until now; the 3.8-kilometre flood canal, which costs $\mathrm{Rp} 600$ billion, has not been able to overcome the 40year cycle floods and annual floods in the city of Medan.

Flood prevention in Medan city is still focused only on the development of physical like; river widening, drainage improvement and flood channel construction. The Medan city government has also used the services of a Dutch consultant to find a flood solution that has become a chronic disease. However, various ways to deal with floods have yet to show encouraging results and are still deadlocked. This condition is further exacerbated by the behaviour of people who do not care about the environment, for example, by littering, leaving the drainage not flowing, and using land without consideration.

In order to achieve the goal of a flood-free city of Medan, the obligation to preserve the environment is not only the duty of the government but also the community as a whole. Neighbourhood as a place to live can only be free of flooding if all of the community is involved and have the awareness to protect the environment. Environmental awareness makes the community always obedient in protecting the environment, which includes community knowledge about the environment, people's appreciation of the environment, and community compliance with regulations relating to the environment (Husni, 2006).

Based on the limits of environmental awareness, efforts to empower communities in tackling floods can be formed based on knowledge, appreciation, and obedience. So, the efforts that can be done are to increase public knowledge about the environment and the danger of flooding, changing patterns of people's behaviour to remain to behave according to the norms of the environment and directing people to be submissive and obedient to the rules.

The knowledge that is not followed by appreciation and obedience becomes a reality of the people of Medan. Based on research on community behaviour in the city of Medan (Natalia, 2014). It was found that the community knew that throwing trash into the river was one of the causes of flooding, but this was still being done. In addition, the Regional Regulation of Medan no. 1 of 2007 about warnings and sanctions for people who throw garbage into the river still only make people indifferent. Not because people do not know, even the regulation has been socialized to the public in the form of signposts at several points of the river. Disposing of trash as if it has been entrenched so that it becomes a bad habit that is difficult to leave. Next, in other studies, Alamsyah (2018) mentioned that the Medan city community does not care about the condition of the drainage so that the drainage depth is only $10 \mathrm{~cm}$ from the previous $60 \mathrm{~cm}$. In fact, people know that the function of drainage is to control flooding.

Knowledge, appreciation, and order can boil down to one word: Empowerment. Community empowerment is an effort to provide empowerment or strengthening to the community. Community empowerment is also defined as the ability of individuals who are united with the community to build the empowerment of the community concerned so that it aims to find new alternatives in community development (Mardikanto, 2014). According to Fahrudin (2012), community empowerment is an effort to enable and independence the community carried out with the following efforts: first, Enabling, which is creating an atmosphere or climate that enables the potential of the community to develop. Empowerment is an effort to build up the community by pushing (encourage), motivating and raising awareness (awareness) will be their potential and strive to develop it. They were second, Empowering, namely increasing capacity by strengthening the potential or power possessed by the community. Empowering includes concrete steps, such as providing various inputs and opening access to opportunities to empower the community. Third, Protecting protects the interests by developing a protection system for the community that is the subject of development. 


\section{JPPM (Jurnal Pendidikan dan Pemberdayaan Masyarakat), 7 (2), 2020 - 174 \\ Ilham Mirzaya Putra, Efi Brata Madya}

Community empowerment aims to do (1) Better institutions; By improving the activities/ actions taken, it is expected to improve institutions, including the development of a business partnership network, (2) Better business; Improvement of education (enthusiasm for learning), improvement of business accessibility, activities and institutional improvement, are expected to improve the business conducted, (3) Improvement of income (better income); With the improvement of the business carried out, it is hoped that it will be able to improve the income it receives, including the income of the family and the community. (4) Improvement of the environment; Revenue improvement is expected to improve the environment (physical and social) because environmental damage is often caused by poverty or limited income. (5) Better living; An improved income level and environmental conditions are expected to improve the living conditions of each family and community. (6) Better community; A better life, supported by a better (physical and social) environment, is expected to lead to better community life.

Flood disasters must be dealt with comprehensively. Physical development alone does not guarantee success. Therefore community participation in the form of empowerment is needed. This study aims to find solutions to flood mitigation based on community empowerment. Community empowerment in the form is increasing knowledge, appreciation, and obedience to the law.

\section{METHODS}

The research method used in this study is a qualitative study using a literature study approach. Research with literature studies does not have to go to the field and meet with respondents. The data needed in the study were obtained from 14 sources of literature or documents. According to Zed (2004), library research (library research), literature searches not only for the initial steps to prepare the framework of research (research design) will be but at the same time utilize library resources to obtain research data (Zed, 2004).

The literature study research is the research that has the same preparation as other studies but the sources and methods of data collection by taking data in the library, reading, recording, and processing research data. Although it looks easy, the study of literature requires high perseverance so that the data and data analysis and conclusions are produced in accordance with the expected research objectives (Fink, 2019). Furthermore, in this research, the literature study was carried out in conjunction with a group discussion forum involving 3 Regional Development lecturers to ensure that the results of the study could be accounted for, valid, and trustworthy (Lehoux et al., 2006).

\section{RESULT AND DISCUSSION}

Based on the Introduction, it is known that flooding in the city of Medan is very much influenced by the condition of the Deli River Basin, deplorable drainage conditions, and the lack of community participation in overcoming the flood disaster. (Sukanto \& Karseno, 1997) identified that there are three main problems of cities in Indonesia: (1) Urban communities in Indonesia are still indifferent; (2) Urban communities in Indonesia are still weak in legal awareness; (3) Law enforcement is still weak.

The entire identification of Sukanto and Karseno (1997) is based on the community. People who still live along the riverbanks actually violate North Sumatra Province Regional Regulation no. 5 of 1995 concerning river boundary line which forbids settling on riverbanks/tributaries, because in addition to disrupting river flow, it is also dangerous for safety. Likewise, the drainage condition filled with garbage becomes very bad/shallow, triggering a flood.

Conditions in the field confirmed that the community did not care about the condition of the drainage in the house or in the environment, which averaged only $10 \mathrm{~cm}$ in-depth. In contrast, initially, the drainage depth was $60 \mathrm{~cm}$. The condition is worsened due to lack of maintenance, so sediments or garbage enter the drainage. So if it rains for just one hour, there will be inundation and flooding. Next, the results of interviews with the community explained 


\section{JPPM (Jurnal Pendidikan dan Pemberdayaan Masyarakat), 7 (2), 2020 - 175}

Ilham Mirzaya Putra, Efi Brata Madya

that government officials did not involve the community to participate in dealing with drainage problems (Hasibuan et al., 2005). Next, it is necessary to discuss how community-based flood disaster management is discussed.

\section{Community Knowledge about the Environment}

The condition of settlements around the Deli River is classified as marked by the tight condition of the buildings, roads that are not patterned and not hardened, public sanitation and drainage are not functioning, and waste has not been managed properly. Moreover, the shantytown is also characterized by low-income levels, social loss norms, and apathetic behaviours. All of these conditions accumulated so that the community became unconcerned with the environment, health, and as if floods were becoming a matter of course.

People in the Deli River basin use the river for bathing, washing, toileting, fishing and quoting garbage that is carried by the current. In addition, the community is also accustomed to throwing garbage in the river because it is considered practical, free of cost, and even has advantages. The problem is that the river is shallow so it can be a vehicle for swimming and playing for children. The community is not worried at all about the potential for diseases originating from murky river water; the condition has been going on for a long time and is a habit that is difficult to remove; even toddlers are also bathed in the river.

Efforts to increase public knowledge about the environment and the dangers of flooding are absolutely necessary, namely through socialization. Socialization is the process of transferring habits or instilling rules and values in a group or community. Some sociologists refer to socialization as a theory of roles (role theory) because socialisation teaches the roles that individuals must perform. The process of resocialization is the giving of a new self-identity to someone, while the process of someone's socialization experiences a revocation of the old identity (Sunarto, 2005).

According to George Herbert Mead, the socialization through which a person can be divided through several stages, one of which is the stage of acceptance of collective norms (generalized stage); at this stage, a person has been considered an adult, can put himself in the position of society at large. Individuals can be responsive, responsible, realize the importance of regulations, work together even with other people they do not know. Self-development at this stage has made individuals citizens in the full sense.

The socialization process is referred to in this research is the resocialization process by giving a new identity to the public the city of Medan, that they are people who care about the environment and desocialisation who tore their old identity as an apathetic public about the environment. This process can further lead to an acceptance of collective norms (generalized stage) so that individuals who feel responsible, aware of the importance of regulations work together even with other strangers in the social order.

Some methods of socialization that can be done are 1) direct socialization, namely the process of socialization carried out by interacting directly with the community. This method is most effective because a detailed explanation of the environment can be done so as to reduce ignorance and incomprehension. This method can be done by visiting from house to house (direct-selling), attending RT meetings, social gatherings, or attending village-level meetings. 2) indirect socialization through intermediaries. This method is time-efficient, but it does not guarantee success because the community does not receive direct socialization from the source. This method is a supporting method as a medium for implementing direct socialization, for example, through moving socialization using certain modes of transportation, billboards, pamphlets, banners, flyers, and warning text.

Socialization is the first step in community-based flood management. So that even though it looks simple, the socialization process is very influential on the sustainability of the program. So that the socialization process must be done carefully, given the very heterogeneous conditions of the community, both education, character, acceptability and understanding of the community. Socialization must be carried out communicatively, which means it must be 


\section{JPPM (Jurnal Pendidikan dan Pemberdayaan Masyarakat), 7 (2), 2020 - 176 \\ Ilham Mirzaya Putra, Efi Brata Madya}

delivered using language that is easily understood and carried out continuously. Communicative does not mean talking a lot but rather to how to convey information appropriately, can be understood, and accepted.

\section{Community Appreciation of the Environment}

Limited socialization has been carried out to the people of Medan who live on the banks of the Deli River. Some research on community behaviour in Deli River banks states that there have been billboards and banners on the prohibition of disposing of garbage and the presence of public garbage cans; this is an indication that socialization has been carried out. But public awareness has not yet arisen. The reason is that they are used to being a marker that knowledge has not turned into appreciation.

Socialization is an effort to enable. It is hoped that the socialization that has been carried out, can increase public awareness and appreciation in protecting the environment. Furthermore, appreciation can be realized from the attitudes and behaviour of the community as an empowering effort. This is also to prepare the community to become independent in facing development, especially in the era of globalization.

Appreciation is a part of the awareness in the form of an element of feeling that leads to beliefs generated through action. Some forms of appreciation can be done in various activities/decisions, including the following (Heriyanto et al., 2013): (1) Ready to be contacted and give time, meaning that the community spends their time, energy, and mind by actively participating in giving ideas, working together, evaluating, and enjoying the results of the environment, (2) Proud of mentioning identity. It means that there is no doubt in society to call themselves environmentally conscious individuals who have the responsibility and awareness to protect the environment. This payment can be actualized by forming an environmentally conscious community consisting of people who live around the river and (3) Always trying to innovate/innovate, which means understanding all the potential that can be used as opportunities in preserving the environment. The innovations made can be made in making biopore holes, recycling used goods, river bank tours, and garbage banks.

Artificial biopore are cylindrical holes with a diameter of $10-30 \mathrm{~cm}$ that are made vertically into the ground. The depth does not exceed the depth of the groundwater level or about $100 \mathrm{~cm}$. Then the hole is filled with organic waste, which can later turn on soil microorganisms. The microorganisms are then going to form pores or tunnels in the soil (biopore), which can accelerate the absorption of water into the ground horizontally. So, if every house or building has biopore, it means that the amount of water-absorbing will undoubtedly be more numerous and can prevent flooding (Karuniastuti, 2014).

Recycle (recycling) is the utilization of waste material to be reprocessed into items similar or other forms. Recycling means changing waste into new products, especially for items that cannot be used for a long time (Wibosono, 2018). Recycling can reduce waste and provide new economic and use values to the goods, making them suitable for reuse, even sold. Furthermore, able to realize the independence of the community.

Managing waste based on the community is a waste management approach based on the community's active participation. If the community as a waste producer performs an active role in waste management, reducing, reusing, and recycling, we need a container that can be a garbage bank. According to Aryenti (2011), a waste bank is a place to store garbage that has been sorted according to type. The garbage bank mechanism is the same as other banks; there are customers, record keeping, and management. If the commercial bank deposited by the customer is money, then the garbage deposited in the bank is a waste of economic value.

Waste banks should be managed by creative and innovative people and have an entrepreneurial spirit in order to increase community income. The working system of the garbage bank is done on a household-based basis by giving rewards to those who have succeeded in sorting and depositing a certain amount of waste. In addition to tackling flooding, a garbage bank is also a greening movement, a means of saving education for the community (Suryani, 


\section{JPPM (Jurnal Pendidikan dan Pemberdayaan Masyarakat), 7 (2), 2020 - 177}

Ilham Mirzaya Putra, Efi Brata Madya

2014). The garbage bank also functions as community empowerment as a form of appreciation of the environment. Until 2013, 1,443 Waste Banks have been established in 56 cities in 19 provinces in Indonesia. Meanwhile, in the city of Medan itself, a garbage bank was present in Sicanang at the end of 2018.

The riverside tourist area in ideal conditions, besides presenting beauty, can also increase the income of the surrounding community. At the end of 2018, the city of Medan already has a colourful but not exciting riverside tourist area. The colourful village was initiated by Pelindo 1 , which is a Community Empowerment program by structuring and developing Deli River watersheds precisely in Hamdan and Sukaraja villages. Of course, the construction of tourist destinations requires a number of funds that are not small, so they must consider the impact on the economy and the environment. Some riverside tours in Indonesia that can become prototypes such as (1) culinary tours of the Martapura river bank, (2) Cimanuk Park, Cimanuk river, Indramayu city, (3) Siti Nurbaya bridge tour, Batang Arau River, Padang City, (4) Culinary tourism on the banks of the Musi river, Ampera Bridge, Palembang, (5) Sekayu Water Front, Musi river, Musi Banyuasin Regency, and (6) Cikapundung Terrace, Babakan Siliwangi, Bandung (Anwar, 2017).

\section{Community Compliance with Regulations}

A law can only be implemented and implemented well if there is a structure that makes it possible for every member of society to realize the ideals of the law. In his book The Behavior of Law, Donald Black states that legal behaviour has its own social structure so that the legal presence varies where people are. Therefore, if we expect good community behaviour, then a good social structure must be created. If the social structure has not subdued the signs of homogeneity, so long as the law enforcement must be selective even though the case is the same (Husni, 2006). That is why the amount of fine littering differs between the regions of DKI Jakarta and North Sumatra.

Furthermore, it also needs to be understood that legal awareness regarding human behaviour, cannot be released from the inner attitude (appreciation). Soemitro (1984), emphasizing that the law that grows from the community then obtains juridical recognition is far better and more robust so that it is easier to implement. The nature of this law is called responsive law (Nonet \& Selznick, 2017), which serves the needs and social interests that are experienced and found directly by the community.

Medan City has a number of environmental regulations, including Regional Regulation No. 6 of 2015 concerning waste management. In this regulation, any individual who litters can be subject to a maximum fine of Rp. 10 million or a maximum of three months in captivity. Meanwhile, for institutions that can be subject to a maximum fine of $\mathrm{Rp} 50$ million or confinement for a maximum of six months. However, this regulation has never had an effect in the midst of society. This is because the social structure does not work optimally, such as the lack of facilities provided in a landfill. Lack of education and the absence of law enforcement, so that legal products are not able to be implemented in people's lives (Alfarisi, 2019). In addition, it is necessary to make a rule that accommodates the community's aspirations so that people are more aware of the law, especially regarding the environment, for example, the mayor's regulation regarding regional policies and strategies of Medan city managing household waste.

Knowledge and appreciation of the environment are actually able to fortify people from behaviour that violates the rules. However, regulations are still needed as a legal umbrella for enforcement if the knowledge and appreciation are set aside one day. This is because the community is a collection of people who are often negligent, so that the rules play a role of reminder. If shown in schematic form, the conclusions of the research community empowerment as flood control efforts can be shown as follows Figure 1. 


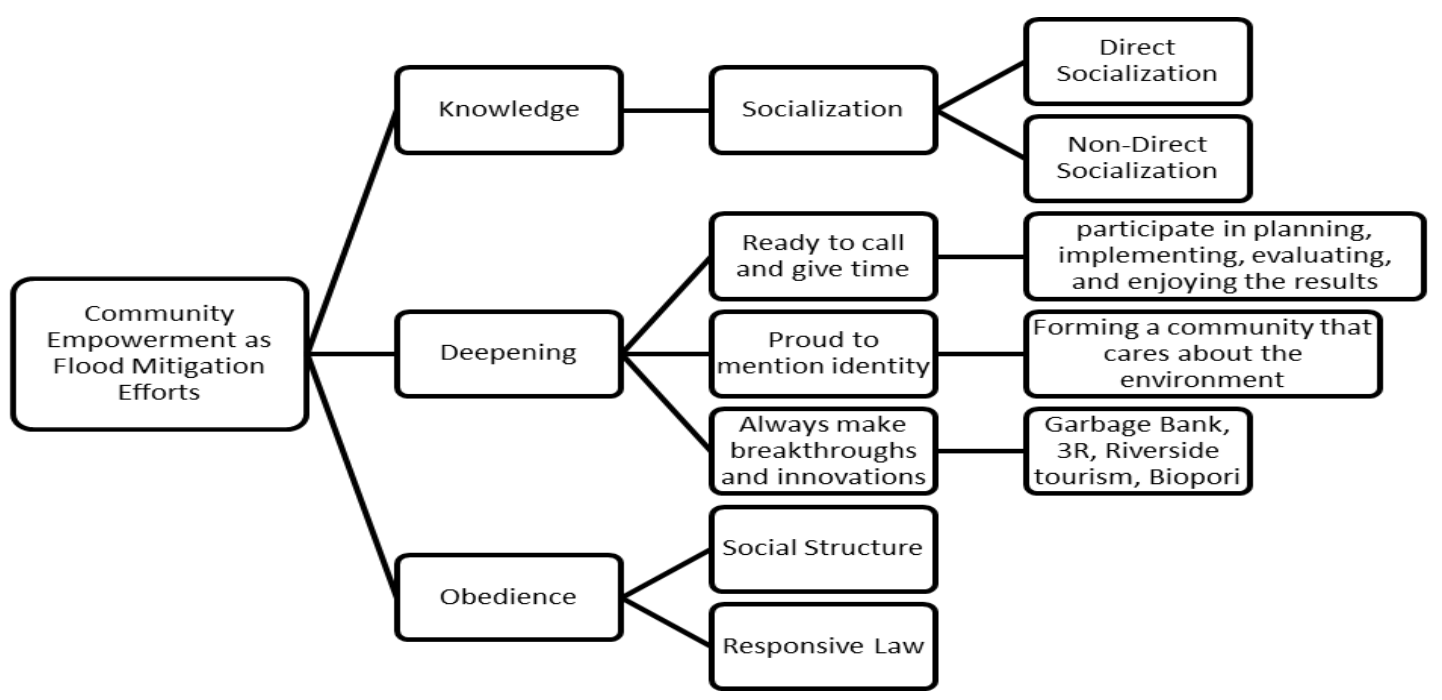

Figure 1. Community Empowerment as Flood Mitigation Efforts

\section{CONCLUSION}

The results of this study are: (1) Community knowledge about the environment must be increased, namely through socialization activities. Socialization activities are the beginning to bring up environmental awareness. Socialization activities can take the form of direct socialization and indirect socialization. (2) Knowledge is not enough without appreciation. The appreciation manifests itself in three decisions /activities, namely; (a) ready to be contacted and give time means the community spends their time, energy, and mind by actively participating in providing ideas (planning), cooperating together (implementing), evaluating, and enjoying the results of the environment. (b) proud of mentioning identity means that there is no doubt in society to call themselves individuals who care about the environment who have the responsibility and awareness to protect the environment. This payment can be actualized by forming an environmentally friendly community consisting of people who live around the river, and (c) always make innovations and breakthroughs. This means understanding all the potential that can be used as opportunities in preserving the environment. The innovations made can be made in making biopore holes, recycling used goods, river bank tours, and garbage banks. And 3) Community compliance with environmental regulations must be enforced in order to have an effect on people's lives. Obedience can be realized if a good social structure condition is created and the existing legal products are responsive laws.

\section{REFERENCES}

Alamsyah, B. (2018). Penanganan problematik banjir Kota Medan berdasarkan pendekatan partisipasi masyarakat. Jurnal Pembangunan Perkotaan, 6(2), 95-101.

http://ejpp.balitbang.pemkomedan.go.id/index.php/JPP/article/view/48

Alfarisi, S. (2019). Sosialisasi Peraturan Daerah Pemerintah Kota Medan tahun 2019.

Anwar, A. (2017). Perancangan kawasan wisata tepian sungai (Studi kasus pada area jembatan kembar Sungguminasa-Gowa) [Universitas Islam Negeri Alauddin Makassar]. http://repositori.uin-alauddin.ac.id/7930/

Aryenti, A. (2011). Peningkatan peranserta masyarakat melalui gerakan menabung pada bank sampah di Kelurahan Babakan Surabaya, Kiaracondong Bandung. Jurnal Permukiman, 6(1), 40-46. http://103.12.84.119/index.php/JP/article/view/134

Fahrudin, A. (2012). Pengantar kesejahteraan sosial. PT Refika Aditama.

Fink, A. (2019). Conducting research literature reviews: From the internet to paper. Sage publications. 
JPPM (Jurnal Pendidikan dan Pemberdayaan Masyarakat), 7 (2), 2020 - 179

Ilham Mirzaya Putra, Efi Brata Madya

Hasibuan, G. M., Tarmizi, H. B., Asren, A., Ramli, R., \& Z, D. (2005). Pengelolaan terpadu banjir Kota Medan. Jurnal Perencanaan \& Pengembangan Wilayah WAHANA HIJAU, 1(1).

Heriyanto, H., Yusup, P. M., \& Rusmana, A. (2013). Makna dan penghayatan profesi pustakawan. Jurnal Kajian Informasi \& Perpustakaan, 1(2), 147-156. https://doi.org/10.24198/jkip.vii2.11004

Husni, M. (2006). Pemberdayaan masyarakat sebagai upaya penegakan hukum. Jurnal Equality, $11(2), 86-93$.

Karuniastuti, N. (2014). Teknologi biopori untuk mengurangi banjir dan tumpukan sampah organik. Swara Patra, 4(2). http://ejurnal.ppsdmmigas.esdm.go.id/sp/index.php/swarapatra/article/view/76

Lehoux, P., Poland, B., \& Daudelin, G. (2006). Focus group research and "the patient's view." Social Science \& Medicine, 63(8), 2091-2104. https://doi.org/10.1016/j.socscimed.2006.05.016

Mardikanto, T. (2014). CSR: Corporate Sosial Responsibility (Tangung jawab sosial korporasi). Alfabeta.

Natalia, M. (2014). Banjir di perkotaan (Studi kasus Kampung Aur Kecamatan Medan Maimun Kota Medan). Universitas Sumatera Utara.

Nonet, P., \& Selznick, P. (2017). Law E society in transition. Routledge. https://doi.org/10.4324/9780203787540

Soemitro, R. H. (1984). Masalah-masalah sosiologo hukum. Sinar Baru.

Sukanto, R., \& Karseno, A. R. (1997). Ekonomi perkotaan. Universitas Gajah Mada.

Sunarto, K. (2005). Pengantar sosiologi. Universitas Indonesia Publishing.

Suryani, A. S. (2014). Peran bank sampah dalam efektivitas pengelolaan sampah (studi kasus bank sampah Malang). Aspirasi: Jurnal Masalah-Masalah Sosial, 5(1), 71-84. https://doi.org/10.46807/aspirasi.v5i1.447

Zed, M. (2004). Metode penelitian kepustakaan. Yayasan Obor Indonesia.

Zevri, A. (2019). Studi pemetaan daerah genangan banjir das sei kambing dengan sistem informasi geografis. TERAS JURNAL-Jurnal Teknik Sipil, 9(2), 165-178. https://doi.org/10.29103/tj.v9i2.233 